\title{
HZSM-5 Catalyst for Cracking Palm Oil to Gasoline: A Comparative Study with and without Impregnation
}

\author{
Achmad Roesyadi *, Danawati Hariprajitno, N. Nurjannah, Santi Dyah Savitri \\ Chemical Reaction Engineering Laboratory, Department of Chemical Engineering, Sepuluh Nopember \\ Institute of Technology, Surabaya, Indonesia 60111
}

Received: 28th September 2012; Revised: 19th November 2012; Accepted: 20th December 2012

\section{Abstract}

It is important to develop a renewable source of energy to overcome a limited source fossil energy. Palm oil is a potential alternative and environmental friendly energy resource in Indonesia due to high production capacity of this vegetable oil. The research studied effect of catalyst to selectivity of biofuel product from cracking of palm oil. The catalyst consisted of HZSM-5 catalyst with or without impregnation. The research was conducted in two steps, namely catalyst synthesized and catalytic cracking process. HZSM-5 was synthesized using Plank methods. The characterization of the synthesized catalysts used AAS (Atomic Absorption Spectroscopy) and BET (Brunaueur Emmet Teller). The cracking was carried out in a fixed bed microreactor with diameter of $1 \mathrm{~cm}$ and length of $16 \mathrm{~cm}$ which was filled with 0.6 gram catalyst. The Ni/HZSM-5 catalyst was recommended for cracking palm oil for the high selectivity to gasoline. (C) 2013 BCREC UNDIP. All rights reserved. (Selected Paper from International Conference on Chemical and Material Engineering (ICCME) 2012)

Keywords: biofuel; catalytic cracking; HZSM-5; palm oil; impregnation

How to Cite: A. Roesyadi, D. Hariprajitno, N. Nurjannah, S.D. Savitri, (2013). HZSM-5 Catalyst for Cracking Palm Oil to Gasoline: A Comparative Study with and without Impregnation. Bulletin of Chemical Reaction Engineering \& Catalysis, 7 (3): 185-190. (doi:10.9767/bcrec.7.3.4045.185-190)

Permalink/DOI: http://dx.doi.org/10.9767/bcrec.7.3.4045.185-190

\section{Introduction}

Economic growth, population, development of the area and development push will need more energy. Energy needs are met during this ingredients from renewable not namely petroleum and coal. However the energy reserves is not always able to meet the entire energy needs in the long term. In anticipation of that condition, it needs to be developed alternative energy from renewable materials. Therefore, this research to develop alternative energy from renewable materials to replace the role of fuel or coal.

\footnotetext{
${ }^{*}$ Corresponding Author.

E-mail: aroesyadi@yahoo.com (A. Roesyadi)

Tel: +62-31-5946480, Fax: +62-81-1371567
}

Renewable energy sources derived from vegetable oils or animal fats. Some vegetable oils have been developed as alternative energy, among others, palm oil, jatropha oil, soy bean oil and so on. Indonesia's palm oil-producing countries is the second largest in the world. The production of palm oil in Indonesia is 12 million tons/year in 2010. Therefore, palm oil is one of the potential raw material for making biofuels. Palm oil has the advantage of more environmentally friendly because it is free of nitrogen and sulfur.

Various processes have been made to produce biofuels. Cracking without catalyst (thermal cracking) take place at high temperature and pressure that requires great energy. Catalytic 
cracking is a way to solve the long carbon chain is long enough to a simple scarbon chain molecule with the aid of a catalyst. The function of catalyst is reducing the activation energy of the substance. Catalyst also control the selectivity of the product. The production of biofuels research was developed through catalytic cracking with different types of catalyst. The purpose of this research was to study the influence of catalyst to biofuel product selectivity.

Palm oil production is on the rise, and the cost of production of palm oil is relatively lower than other plant oils. Indonesia as a country of tropical land that still has a quite extensive may be large to be developed both through capital investment and foreign scale plantation of the people. Palm oil contains varied fatty acids both saturated and unsaturated, as in Table 1.

Cracking of palm oil using $\mathrm{CaO}$ catalyst at temperatures ranging from 450 to $500{ }^{\circ} \mathrm{C}$ using the $250 \mathrm{~mL}$ glass vessel result of $72.5 \%$ of organic liquid product yield and $8.5 \%$ of coke yield [1]. But Tamunaidu's experiment showed that the highest palm oil conversion was $93.5 \mathrm{wt} \%$ at $500{ }^{\circ} \mathrm{C}$ and 30 $\mathrm{s}$ using zeolite REY [2]. The presence of zeolite type catalysts in batch arrangement at temperature between 350 and $440 \quad{ }^{\circ} \mathrm{C}$ with rapeseed oil as raw material gave a yield of liquid condensate 85 to $90 \mathrm{wt} \%$ [3]. Chew and Bhatia studied the effect of HZSM-5 (different Si/Al ratios), beta zeolite, SBA-15 and AlSBA-15 as physically mixed additives with cracking catalyst Rare earth-Y (REY). REY catalyst alone gave 75.8 $\mathrm{wt} \%$ conversion with $34.5 \mathrm{wt} \%$ of gasoline fraction

Table 1. Composition of fatty acid in palm oil [4]

\begin{tabular}{cc}
\hline Fatty acid (> 1\%) & Composition $\mathbf{( \% )}$ \\
\hline Fatty acid ( $>\mathbf{1 \%})$ & \\
Miristic acid & 3 \\
Palmitic acid & 30 \\
Stearic acid & 3 \\
Oleic acid & 55 \\
Linoleic acid & 8 \\
Fatty acid (<1 \%) & \\
Carotenoid & $500-700$ \\
Tokoferol / tokotrienol & $600-1000$ \\
Sterol / sitosterol & $218-370$ \\
Campesterol & $90-151$ \\
Stigmasterol & $44-66$ \\
colesterol & $7-13$ \\
Other & $2-18$ \\
\hline
\end{tabular}

yield using CPO, whereas with UPO, the conversion was $70.9 \mathrm{wt} \%$ with gasoline fraction yield of 33.0 wt\%. HZSM-5, beta zeolite, SBA-15 and AlSBA-15 as additives with REY increased the conversion and the yield of organic liquid product. [5]. The presence of zeolite catalyst $\mathrm{NaY}$ and clinoptilolite were carried out with rapeseed, sunflower, soybean and jatropha oils as well as with used frying oils. Liquid condensates with yields of 85 to $90 \%$ relative to the input oil were obtained at temperatures of 350 to $440{ }^{\circ} \mathrm{C}$ applied for the period of 20 to $30 \mathrm{~min}$ [6].

Biswal and Sharma [7] investigated cracking of jatropha oil without catalyst under isothermal condition, atmospheric pressure and the flow of nitrogen was maintained at $120 \mathrm{ml} / \mathrm{h}$. It was observed that as the time of cracking increases, the cracking of Jatropha oils proceeds to completion with about $73 \%$ liquid yield, $26 \%$ gaseous product and about less than 1\% char.

Production costs are high because the technology is complicated and long process. Researcher have resolved this issue by using a catalyst to accelerate the reaction separately. But the price of commercial catalyst is very expensive. The research used a synthesis zeolite because this raw materials are abundance availability in Indonesia. The synthesized zeolite was impregnated using metal of $\mathrm{Ni}, \mathrm{Cu}$ and $\mathrm{Zn}$.

Zeolite is a solid of crystal structure with microscopy shaped three dimensions, composed of aluminum, silicon and oxygen as the primary structure. The diameter of the cavity is between 3 and $10 \AA$. Empirical formula of zeolite is $\mathrm{M}_{\mathrm{x} / \mathrm{n}}\left(\mathrm{AlO}_{2}\right)_{\mathrm{x}}\left(\mathrm{SiO}_{2}\right)_{\mathrm{y}} \cdot \mathrm{mH}_{2} \mathrm{O}$ where $\mathrm{M}$ is cation of neutralising with valensi of $n$, where $n$ is expressed as the number of tribes. Zeolite ZSM-5 catalyst could increase the yield of olefin and octane [8].

\section{Materials and Methods}

\subsection{Materials}

Catalytic cracking used palm oil as raw material. The palm oil was used through RBD (Refined, Bleached and Deodorized) process with Bimoli trademark. The composition of palm oil was analyzed by GC (Gas Chromatograph) methods, shown in Table 2. This research used zeolite synthesis as catalyst. The materials of zeolite synthesis consists of Sulfate aluminum which is solid white crystals with a molecular weight of 342.14 and a density of $169 \mathrm{~g} / \mathrm{ml}$ at $16{ }^{\circ} \mathrm{C}$. Cupprum sulphate appearance crystal blue colored that soluble in water and methanol. Cuprum sulfate has a molecular weight of $249.68 \mathrm{~g} / \mathrm{mol}$, 
Table 2. The composition of palm oil with RBD process

\begin{tabular}{llc}
\hline \multicolumn{2}{l}{ Name of fatty acid } & $\begin{array}{c}\text { Fatty acid } \\
\text { (\%) }\end{array}$ \\
\hline C8 & Caprilic & 0.000 \\
C10 & Capric & 0.000 \\
C12 & Lauric & 0.262 \\
C14 & Myristic & 1.012 \\
C16 & Palmitic & 38.201 \\
C18 & Stearic & 3.637 \\
C18:1 & Oleic & 45.962 \\
C18:2 & Linoleic & 10.926 \\
\hline
\end{tabular}

specific gravity at $20{ }^{\circ} \mathrm{C}$ is 2.286 . Zinc sulfate is a solid with a molecular weight of $179.43 \mathrm{~g} / \mathrm{mol}$. Sodium hydroxide is hygroscopic with a molecular weight of $40 \mathrm{~g} / \mathrm{mol}$. Nickel sulfate is a colorless crystal solid with a molecular weight of 262.85 $\mathrm{g} / \mathrm{mol}$. Ammonium chloride is a solid crystalline powder with a molecular weight of $53.49 \mathrm{~g} / \mathrm{mol}$. Sulfuric acid p.a. (Pro analysis) of 95-97\% purity and butanol is a colorless liquid with a $\mathrm{pH}$ of 7 , density of $0.81 \mathrm{~g} / \mathrm{cm}^{3}$. The materials were purchased from Merck, Germany.

\subsection{Preparation of Catalyst}

The two tipe of catalyst were synthesized include HZSM-5 without impregnation and HZSM5 impregnated by a solution of $\mathrm{CuSO}_{4} .5 \mathrm{H}_{2} \mathrm{O}$, $\mathrm{NiSO}_{4} .7 \mathrm{H}_{2} \mathrm{O}$ and $\mathrm{ZnSO}_{4} .7 \mathrm{H}_{2} \mathrm{O}$. This research consisted of catalyst preparation, cracking and analysis of results. Catalysts impregnation used the Romero's procedure (1997). HZSM-5 catalyst was calcinated on an oven at $110{ }^{\circ} \mathrm{C}$ for 2 hours, and cooling in the desiccators. Catalytic cracking was done in a microreactor fixed bed with diameter of $1 \mathrm{~cm}$, length of $16.4 \mathrm{~cm}$ and was filled with $0.6 \mathrm{~g}$ of catalyst in Figure 1. Temperature of cracking was $350-500{ }^{\circ} \mathrm{C}$ and $\mathrm{N}_{2}$ flow rate was $120-160$ $\mathrm{ml} /$ minute. The reaction result was analyzed by gas chromatography of FID (Flame Ionization Detector).

\subsection{Cracking of Palm Oil}

The transesterification of palm oil with catalytic cracking was done in a micro-reactor coating by heater and $1 \mathrm{~g}$ weight of catalyst. Palm oil was fed to the reactor at $350{ }^{\circ} \mathrm{C}$, then the tank were flowed by nitrogen gas with rate of 100-160 $\mathrm{ml} / \mathrm{min}$. The oil vapor and nitrogen gas were flowed into the fixed bed reactor at temperatures of 350 to $500{ }^{\circ} \mathrm{C}$. Catalytic cracking was carried out during the 120 minutes. The result was analyzed by gas chromatography method of FID (Flame Ionization

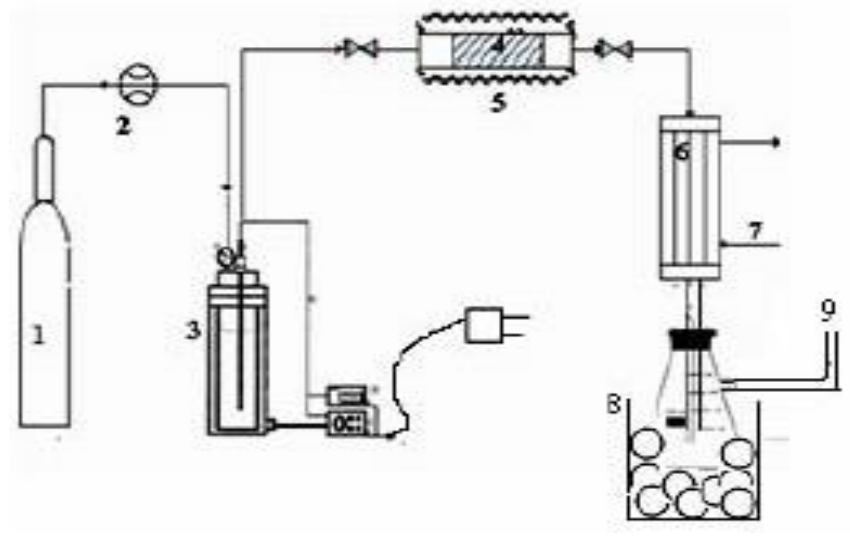

Figure 1. Reactor for palm oil cracking. (1) Flow rater of $\mathrm{N}_{2}$, (2) Flow meter, (3) heater, (4) catalyst, (5) microreactor, (6) condensor , (7) Cooling water, (8) sample of liquid, (9) sample of gas

Detector) column HP PORAPLOT QO4. The equipment of cracking can be seen in Figure 1.

\section{Results and Discussion}

\subsection{Characterization of catalyst}

The synthesized catalyst were characterized by mean Atomic Absorption Spectroscopy (AAS), Brunauer Emmet Teller (BET) and XRD (X-ray Diffraction) methods. AAS was used to see the ratio $\mathrm{Si} / \mathrm{Al}$ and the levels of catalyst of $\mathrm{Cu}, \mathrm{Ni}$ and $\mathrm{Zn}$. Measurement of surface area and the average pore size used the method of BET (Brunauer Emmet Teller). The type and structure of crystals catalyst were analyzed using XRD. Table 3 showed results of characteristization of catalyst.

Minimum pore size length of catalyst was $8 \AA$ and surface area was more than $100 \mathrm{~m}^{2} / \mathrm{g}$ [6]. Surface area increased by the addition of a few metal, because the surface was covered by metal catalyst. The reducing of surface area didn't mean the reducing of the catalyst effectiveness, but adding of the active site affected the rate of the reaction [7].

\subsection{Influence of temperature on yield of gasoline, kerosene and diesel with HZSM-5 catalyst without impregnation and with impregnation metal of $\mathrm{Ni}, \mathrm{Cu}$ and $\mathrm{Zn}$}

The purpose of active metal impregnation on catalyst surface added the active side on the catalyst surface, so the activity of the catalyst increased. Figures 2 to 4 showed the influence of temperature on yield of biofuels by catalyst with or without impregnation. The influence of activity catalyst was done by flow rate of $\mathrm{N}_{2}$ gas is 130 
Table 3. Characterizations of HZSM-5 Catalyst

\begin{tabular}{|c|c|c|c|c|}
\hline The name of catalyst & $\begin{array}{l}\mathrm{Si} / \mathrm{Al} \\
(\mathrm{m} / \mathrm{m})\end{array}$ & $\mathrm{Ni}, \mathrm{Cu}, \mathrm{Zn}$ & $\begin{array}{l}\text { Pore size } \\
\quad(\AA)\end{array}$ & $\begin{array}{l}\text { Surface area } \\
\left(\mathrm{m}^{2} / \mathrm{g}\right)\end{array}$ \\
\hline HZSM-5 & \multirow{4}{*}{243} & 0 & 13.255 & 213.3524 \\
\hline HZSM - $5 /$ Ni $5 \%$ & & 4.98 & 13.176 & 194.2372 \\
\hline HZSM - $5 / \mathrm{Cu} 5 \%$ & & 5 & 13.249 & 201.1762 \\
\hline HZSM - 5/ Zn 5\% & & 4.20 & 13.962 & 192.9966 \\
\hline
\end{tabular}

$\mathrm{ml} / \mathrm{min}$ and variations of temperature. Figure 2 shows that the highest yield of gasoline is obtained by Zn/HZSM- 5 catalyst on temperature of $450{ }^{\circ} \mathrm{C}$ is $29.38 \%$. This is due to $\mathrm{Ni}$ metal impregnation to HZSM-5 catalyst is distributed evenly on the surface of the metal, so that the active site catalysts having increased. Increasing of the active site is followed increasing of yield of gasoline.

Figure 3 showed the highest yield of the kerosene was obtained by HZSM-5 Ni-catalyst on temperature of $500{ }^{\circ} \mathrm{C}$ at $14.95 \%$. Figure 4 showed the highest yield of the diesel was obtained by HZSM-5 catalyst at $24.19 \%$. From of the three types of impregnation catalyst, only the catalyst of HZSM-5/Ni which increased in yield with the inclusion of metal catalyst of Ni on HZSM-5.

\subsection{Influence of temperature on the} selectivity of gasoline, kerosene, and diesel for $\mathrm{Ni} / \mathrm{Cu} / \mathrm{Zn}$-HZSM-5 catalyst

Figures 5 to 7 showed the influence of temperature on biofuel selectivity at catalytic cracking with or without impregnation of catalyst. Figure 5 showed selectivity of gasoline by HZSM- 5 catalyst on $400{ }^{\circ} \mathrm{C}$ at 0.43 , by Ni/HZSM- 5 catalyst on $350{ }^{\circ} \mathrm{C}$ at 0.85 , by Zn/HZSM- 5 catalyst on $450{ }^{\circ} \mathrm{C}$
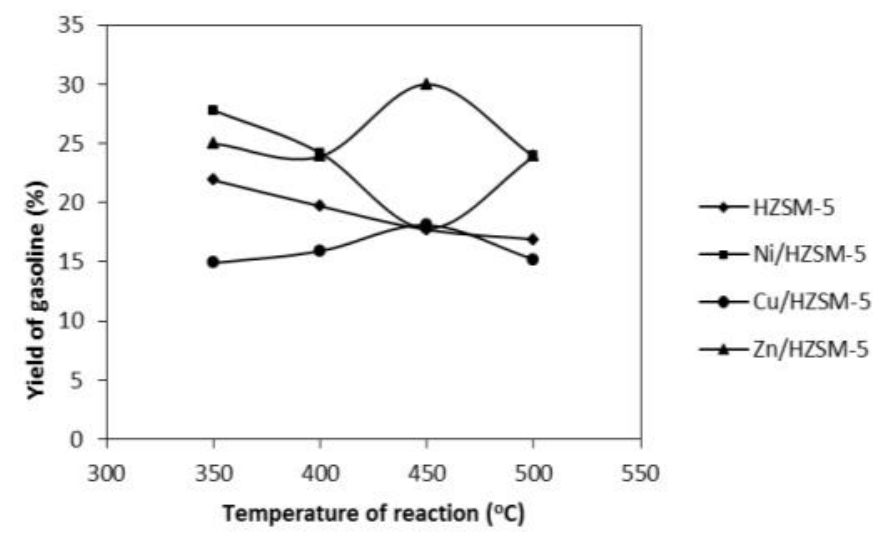

Figure 2. The influence of reaction temperature on yield of gasoline at $\mathrm{N}_{2}$ flow rate of $140 \mathrm{ml} / \mathrm{min}$ at 0.40 and by $\mathrm{Cu} / \mathrm{HZSM}-5$ catalyst on $500{ }^{\circ} \mathrm{C}$ at 0.45 . Figure 6 showed selectivity of kerosene by HZSM- 5 catalyst on $450{ }^{\circ} \mathrm{C}$ at 0.26 , by Ni/HZSM- 5 catalyst on $350{ }^{\circ} \mathrm{C}$ at 0.34 , by Zn/HZSM- 5 catalyst on $350{ }^{\circ} \mathrm{C}$ at 0.19 and by $\mathrm{Cu} / \mathrm{HZSM}-5$ catalyst on $400{ }^{\circ} \mathrm{C}$ at 0.22 . Figure 7 showed selectivity of diesel by HZSM- 5 catalyst on $400{ }^{\circ} \mathrm{C}$ at 0.24 , by $\mathrm{Ni} / \mathrm{HZSM}-5$ catalyst on $350{ }^{\circ} \mathrm{C}$ at 0.7 , by Zn/HZSM5 catalyst on $350{ }^{\circ} \mathrm{C}$ at 0.10 and by $\mathrm{Cu} / \mathrm{HZSM}-5$ catalyst on $400{ }^{\circ} \mathrm{C}$ at 0.13 . Ni-HZSM- 5 catalyst was selectivety of gasoline, kerosene, diesel at temperature of $350{ }^{\circ} \mathrm{C}$ because adding of Ni metal followed increasing acid side of HZSM-5.

\section{Conclusions}

Cracking product of vegetable oil was friendlier than cracking product of crude oil. Using of HZSM-5 catalyst with or without impregnation decrease activation energy of cracking reaction. The result of characteristic catalyst was the surface area and pore size suitable with the criteria of a standard catalyst. The product distribution at reactor temperature of $450{ }^{\circ} \mathrm{C}$ and rate of $\mathrm{N}_{2}$ gas of $130 \mathrm{ml} / \mathrm{min}$ by catalyst HZSM-5 were $17.11 \%$ of gasoline, $14.89 \%$ of kerosene and

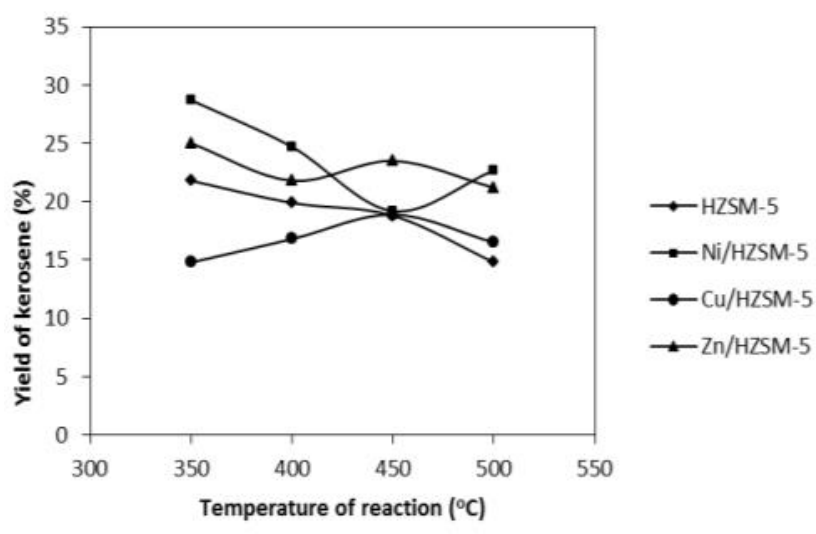

Figure 3. The influence of reaction temperature on yield of kerosene at $\mathrm{N}_{2}$ flow rate of $130 \mathrm{ml} / \mathrm{min}$ 


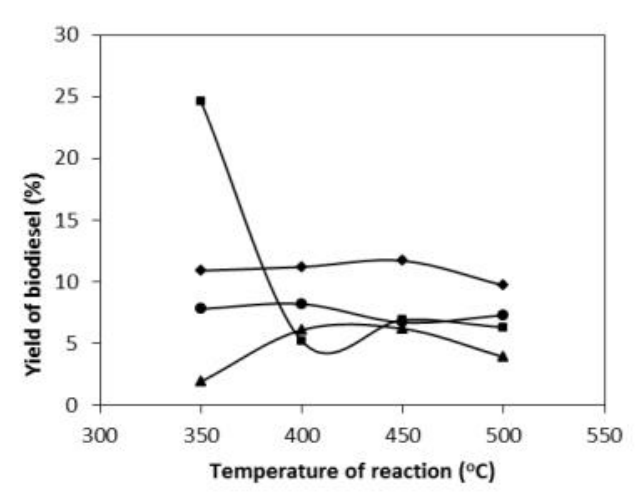

$\rightarrow$ HZSM-5

$\rightarrow-\mathrm{Ni} / \mathrm{HZSM}-5$

$\rightarrow \mathrm{Cu} / \mathrm{HZSM}-5$

$\rightarrow \mathrm{Zn} / \mathrm{HZSM}-5$

Figure 4. The influence of reaction temperature on yield of diesel for $\mathrm{N}_{2}$ flow rate of $130 \mathrm{ml} / \mathrm{min}$
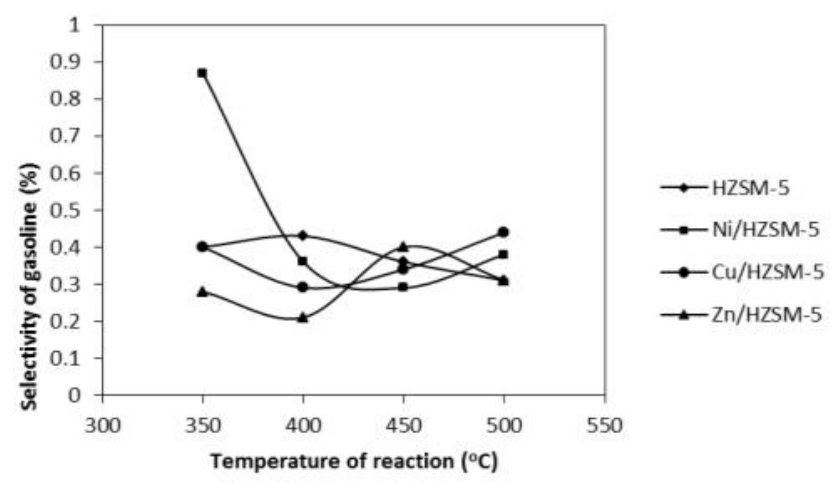

Figure 5. The influence of reaction temperature on selectivity of gasoline for $\mathrm{N}_{2}$ flow rate of 130 $\mathrm{ml} / \mathrm{min}$

$10.86 \%$ of diesel. For the same condition by catalyst Ni/HZSM-5 were $17.55 \%$ of gasoline, $13.48 \%$ of kerosene and $5.84 \%$ of diesel. And then by catalyst $\mathrm{Cu} / \mathrm{HZSM}-5$ were $18.05 \%$ of gasoline, $13.30 \%$ of kerosene and $5.72 \%$ of diesel. All of the catalysts were selectivity for formation of gasoline and kerosene. The Ni/HZSM-5 catalyst recommended for cracking palm oil for the selectivity to gasoline especially.

\section{Acknowledgement}

The author acknowledged to student, associate of lecture and the crews of chemical reaction engineering laboratory, Sepuluh Nopember Institute of Technology.

\section{References}

[1] Junming, X., Jianchum, J., Yunjuan, S. (2010). Biofuel Production From Catalytic Cracking of Woody Oils. Bioresource Technology. 101 : 5586 5591.

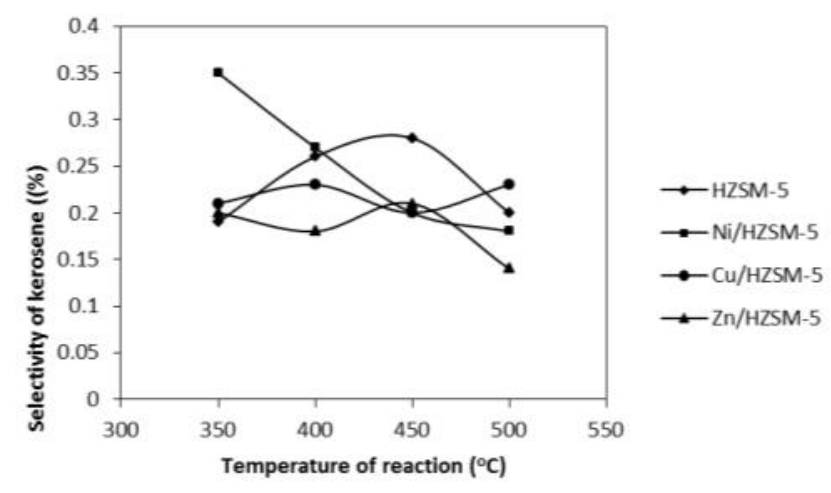

Figure 6. The influence of reaction temperature on selectivity of kerosene for $\mathrm{N}_{2}$ flow rate of 130 $\mathrm{ml} / \mathrm{min}$

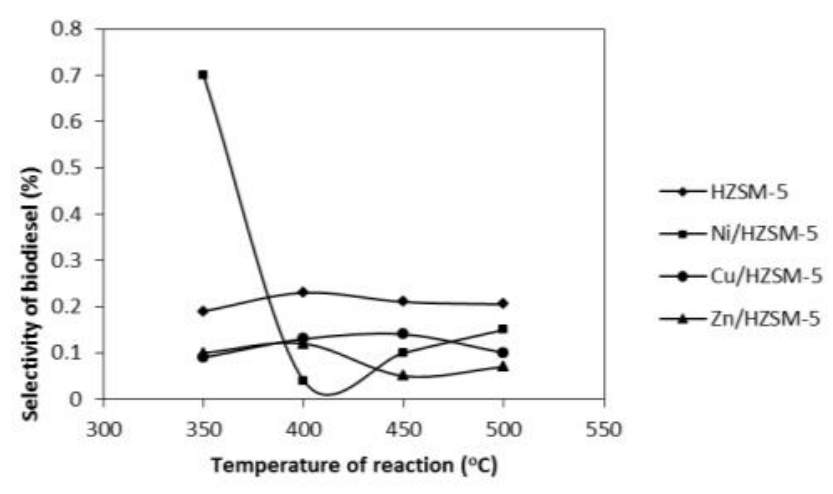

Figure 7. The influence of reaction temperature to selectivity of diesel for $\mathrm{N}_{2}$ flow rate of $130 \mathrm{ml} /$ $\min$

[2] Tamunaidu, P., Bhatia, S. (2007). Catalytic Cracking of Palm Oil for The Production of Biofuels : Optimization Studies. Biorsource Technology. $98: 3593-3601$.

[3] Buzetzki, E., Sidorova, K., Cvengrosova, Z., Cvengros, A.K.J. (2011). The Influence of Zeolite Catalysts on The Products of Rapeseed Oil Cracking. Fuel Processing Technology. 92 : $1623-$ 1631.

[4] Hui YH. (1996). Bailey's Industrial Oil and Fat Products : Industrial ans Consumer Non Edible Product from Oil and fats. vol. 5. 5th ed. John Wiley \& Sons. New York

[5] Biswas, S., Sharma, D.K. (2012) Studies on Cracking of Jatropha Oil. Journal of Analytical and Applied Pyrolysis, 99: 122-129

[6] Buzetzki, E., Sidorova, K., Cvengrosova, Z., Cvengros, J. (2011). Effects of Oil Type on Products Obtained by Cracking of Oils and Fats. Fuel Processing Technology 92 : 2041-2047 
[7] Chew, T.L., Bhatia, S. (2009). Effect of Catalyst Additives on The Production of Biofuels From Palm Oil Cracking in A Transport Riser Reactor. Bioresource Technology 100 : 2540 - 2545

[8] Bekkum VH, Flaningen EM, and Jansen JC. (1991). Introduction to Zeolite Science and Practice. New York.
[9] Romero, M.D. (1997). Influence of the preparation methode and metal precussor compound on the bifunctional Ni/HZSM-5 catalysts, Industrial Engineering Chemistry Research, 36(9): 3533-3540 